\title{
CMOSプロセスを用いたシリコンフォトニクス
}

\author{
馬場 俊彦 \\ 横浜国立大学 ( $\overline{7} 240-8501$ 神奈川県横浜市保土ヶ谷区常盤台79-5)
}

\section{Silicon Photonics Based on CMOS-Compatible Process}

\author{
Toshihiko BABA
}

Yokohama National University, 79-5 Tokiwadai, Hodogayaku, Yokohama, Kanagawa 240-8501

(Received November 3, 2013)

\begin{abstract}
Si photonics technologies enable dense integration of such photonic devices as passive devices, $\mathrm{p} / \mathrm{n}$ modulators, and Ge photo-diodes. The CMOS-compatible foundry services of Si photonics achieve wafer-scale production of photonic integrated circuits with sophisticated functions as well as low cost by a multi-project-wafer process. Recently, they also include the fabrication of complicated photonic crystals and related nanostructures in their recipes. Thus, the research and development of photonic devices and integrated circuits are changing rapidly and becoming more design- and system-oriented. This paper reports such new trends and some example demonstrations.
\end{abstract}

Key Words: Silicon photonics, CMOS process, Foundry service, Photonic crystal, Optical interconnect

\section{1.はじめに}

シリコン $(\mathrm{Si})$ フォトニクスは1980年代に研究が始まっ た当初 ${ }^{1)}$ から, 電子集積回路 (Large-Scale Integrated Circuit: LSI)の製造インフラの活用や光・電子融合が標 榜されてきた。長い基礎研究の後, 2000年以降の進展に より光源を除く様々な光デバイスが開発され ${ }^{2-9)}$, 一定 の性能に達した。2006年以降, 本格的にCMOS互換プロ セスを用いたウエハスケールの光集積が報告され ${ }^{10)}$,さ らに高性能計算機等に用いられる光トランシーバとして 実用化に至った。また2008～2010年に同様のプロセスを 用いた一般向け製作代行(いわゆるファウンダリ)サービ スや, これを利用した研究が登場し, 最近は世界的に急 増している感がある。

当然のことながら，このようなサービスを利用する と, 各研究機関の個別プロセスを用いたのとは比較にな らない大規模 · 大面積, 高再現性・高歩留まりな製作が 可能になる，そのため，従来の個々のデバイス開発の枠 を超えた，高機能な光集積回路やシステム応用を目標と することが可能になる。本稿では既に一変しつつあるこ の分野の研究開発環境を報告し, 関連する研究者・技術 者の意識改革や新しいシステム開発を促したい。

$$
\text { 2. Siフォトニクスファウンダリ }
$$

現在, 一般利用者向けサービスを提供する3つのファ ウンダリがある。すなわちべルギーのIMEC (Interuniversity Microelectronics Centre) ${ }^{\dagger 1}$ ，フ ラン ス のLETI (Laboratorie d'Electronique des Technologies de 1'Information $)^{\dagger 2}$, シンガポールのIME (Institute of Microelectronics) ${ }^{\dagger 3}$

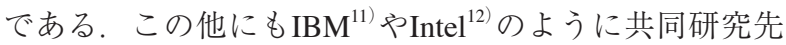
への限定サービスを行う企業，技術開発中でサービスに 至っていない機関もあり，さらに外部発表がない機関も あると思われる。

多くの場合，Si LSIの旧世代の製造プロセスが転用さ

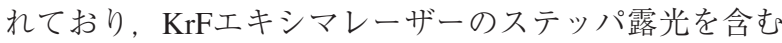
$180 \mathrm{~nm}$ プロセスから始まり，ファウンダリによっては ArFによる $130 \mathrm{~nm}$ プロセス，液浸 $\mathrm{ArF} に よ る 90 \mathrm{~nm}$ 以下の プロセスへとルール縮小が進められている。いずれの ファウンダリもFig. 1，2に示すように，200〜300 mm $\phi$, Si層厚200〜300 nmのSilicon-On-Insulator (SOI) ウエハを 用い，光配線のためのSi細線導波路やリブ導波路，各種 パッシブ部品, ファイバ結合のためのスポットサイズ変 換器や回折格子，位相や光強度を調整するためのヒー夕

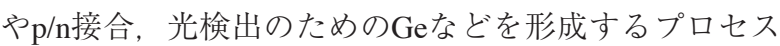
レシピをもっている。エピタキシャル成長されるGeは

\footnotetext{
${ }^{\dagger 1} \mathrm{http} / /$ www2.imec.be/be_en/home.html

${ }^{\dagger 2}$ http://www-leti.cea.fr/en/

${ }^{\dagger 3}$ http://www.ime.a-star.edu.sg/
} 


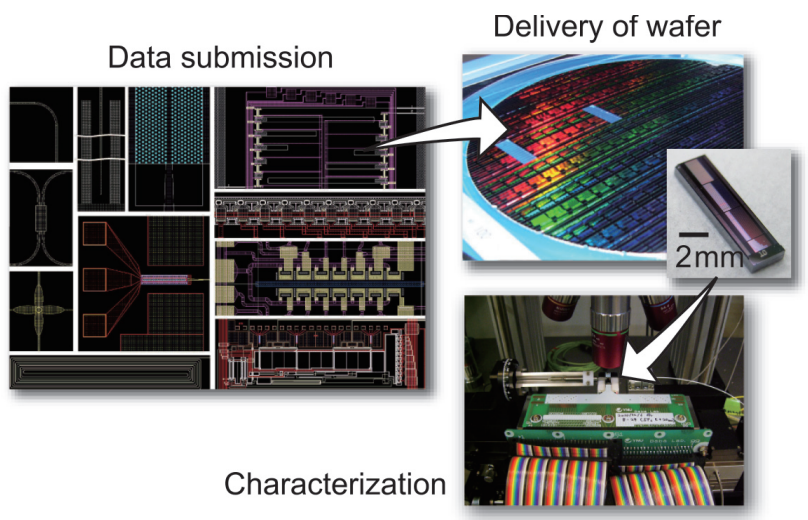

Fig. 1 Research and development using foundry service of $\mathrm{Si}$ photonics CMOS process.

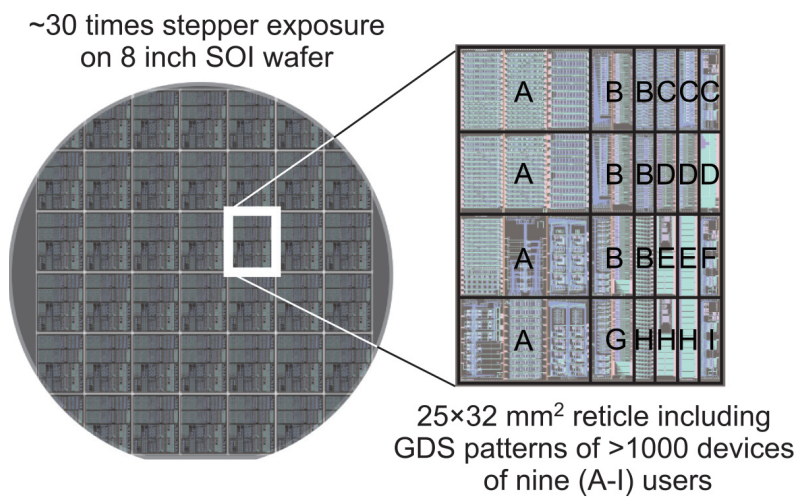

Fig. 2 Schematic of MPW process.

もちろん, 他のプロセスも層厚方向の構造スケールや曲 線を多用する形状がLSIのそれらとは異なるため，旧製 造ラインを転用してすぐにSiフォトニクスが製作できる 訳ではなく，専用の技術的蓄積が必要である。

ところでこのようなサービスを単独利用しようとする と, 必要となるレシピにも依るが, 一千万円単位の費用 がかかる(パッシブ部品のみであればはるかに安い)。こ れを例えば大学の研究室が単独で負担するのは困難かも しれない，しかし多数の利用者で分担すれば，費用を大 幅に下げられる。これが複数プロジェクトウエハ(Multi Project Wafer: MPW)，もしくはシャトルといわれるプロ セスである. 上記のステッパ露光にはレチクルと呼ばれ るフォトマスクセットが用いられる。 このレチクルの面 積をFig. 2のように利用者が分け合い, それに比例した 費用を負担して, 最終的にダイシング分離されたチップ を受け取る。例えばレチクル面積を50分割すれば，その 一区画の費用負担は数十万円に抑えられ, 大学研究室で も利用しやすくなる。ただLMPWを実施するには，仕 様と日程, 支払いや納品を管理する空口機関が必要とな る。欧州ではePIXfab, 米国ではOpSISがこのような密口 として活動している。ここではデバイスライブラリやプ ロセスデザインキット(Process Design Kit: PDK)の提供, その範囲内での性能保証, デバイス評価やパッケージン グの代行サービスも用意されている(それらの利用に よって費用が析違いに変わる). 残念ながら日本にはこ のような機関がなく，筆者自身が空口になった8例など
限定的である(そのため，MPWに興味がある読者は一報 されたし)。単独利用に比べるとMPWは費用が圧倒的に 下がる代償として，一般に仕様が制約され，納期が遅く なり, プロセスの混在による若干の精度低下も生じる。 また知財権・著作権の扱いが難しくなる点も認識してお く必要がある。

\section{3. 設計と評価を中心とする研究開発}

製作プロセスについて，ある程度はファウンダリと協 議できる。しかし共同体制を組まない限り，条件の詳細 は開示されない，また単独利用でない限り，困難を伴う 特殊プロセスを一利用者が求めるのも難しい，さらに $\mathrm{p} / \mathrm{n}$ 接合やGeを含むフルレシピのウエハは標準的な納期 が半年に及ぶ(パッシブのみであれば1〜2ケ月)。よって 自由に試作を繰り返すこともできない，そこでファウン ダリの標準仕様と関連情報を元に可能な限りデバイスや 回路を設計し, 提出が求められる業界標準GDS IIフォー マットのデータに反映させる。 具体的には有限要素法や 時間領域有限差分法を用いて光波伝搬を予測し，低損失 化, 広带域化, 許容誤差範囲の拡大をはかる。またヒー 夕の熱解析, $\mathrm{p} / \mathrm{n}$ 接合のキャリア特性解析も設計に反映 させる。 これらには3次元解析が必須であり, 中途半端 な2次元解析では定量予測ができない，逆に言えば，正 しい3次元解析は驚くほど試作デバイスの特性と一致す る.

Fig. 2 は $25 \times 32 \mathrm{~mm}^{2}$ のレチクルを9機関で分割する例を 表して㧍り，機関FやIが占める面積は約 $2 \times 8 \mathrm{~mm}^{2}$ と小 さい。しかしSiフォトニクスに多用される細線導波路は 標準的な断面積が $0.2 \times 0.4 \mu \mathrm{m}^{2}$, 曲げ半径が5 $\mu \mathrm{m}$ と小さ く, 光回路のレイアウト自由度が高い, そのため, 単純 なデバイスであれば上記の面積に数百個が収納できる. これに対して，例えばTable 1のような多くのマスクレイ

Table 1 Example of layers in GDS II format data.

\begin{tabular}{cc}
\hline Layer No. & Devices \\
\hline 1 & Si wires and wide areas \\
2 & Rib \\
3 & PhC \\
4 & Silica trench at SSC \\
5 & Clad window at PhC \\
6 & Clad window at Si wire \\
7 & Facet deep trench \\
8 & Heater isolation trench \\
9 & Al wire \\
10 & Contact hole (heater) \\
11 & Heater (upper layer) \\
12 & Heater (lower layer) \\
13 & Contact hole (pn) \\
14 & Si n implant \\
15 & Si p implant \\
16 & Si n + implant \\
17 & Si p implant \\
18 & Ge $\mathrm{n}$ implant \\
19 & Si p implant for PD \\
20 & Ge window \\
21 & Probing/bonding pad \\
22 & Si N $_{4}$ \\
23 & Grating \\
\hline
\end{tabular}


ヤーの部品を設計し，ファウンダリから情報提供される 露光の近接効果補正を施したデー夕を生成する必要があ る。もし機関Aのように大面積を占有すると, 設計や確 認の作業は膨大になる。 ところが現状，このような光回 路設計には，LSIのような専用CADも，電子回路自動設 計(Electronic Design Automation: EDA), 設 計ルール チェック (Design Rule Check: DRC) といった支援ツール も存在しない。商用環境としては, 市販の汎用CADソ フト程度しかないのである。我々はこの作業に関わる 様々なリソースを増強し，また大容量のデー夕を生成す るための自動生成プログラムを作成，利用している．

一方，チップが納品されたら，それを迅速に評価し， 次の試作日程に間に合うように設計にフィードバックさ せる。しかし前述のようにチップに含まれるデバイスは 多く，またFig.2からわかるように，ステッパ露光によ り同内容のチップが数十個は製作されるので, 全てを評 価する作業は設計に劣らず膨大となる。我々は伝搬特性 評価系, 群遅延評価系, 高速信号評価系 $\times 2$ を整備して いる。そしてFig.1のように，スポットサイズ変換器を 搭載したチップ端面に光ファイバを結合させ，多芯プ ローブやプリント基板へのボンディングにより直流/高 周波電気制御を行っている. 光入出力用に回折格子を採 用し，上方から2本のファイバを近接結合させ，電気制 御にはプローブカードを利用する例も見られる。この場 合, 全てが上方からのアクセスなので, チップ分離せず にウエハ単位での評価が可能になる。

\section{4. デバイス性能}

多くの場合，Siが透明な波長1.3〜1.6 um帯に向けてデ バイスが開発される。光配線の基本となる細線導波路は 扁平断面のため偏波依存性が大きく, 主にTE偏波で用 いられる。製作摇らぎによる光散乱に起因した伝搬損失 は $3 \mathrm{~dB} / \mathrm{cm}$ が標準的であるが, $90 \mathrm{~nm}$ 以下のプロセスでは $1 \mathrm{~dB} / \mathrm{cm}$ に迫ってきた。偏波無依存化には正方断面が有 効であるが損失が増える，光回路の大型化を許せば，リ ブ型導波路を偏波無依存化する方法もある。また，円孔 配列から成るフォトニック結晶導波路も製作される。 こ れは構造が複雑で損失が $10 \mathrm{~dB} / \mathrm{cm}$ 以上と大きいので, ス ローライト生成など特殊用途に向いている.

パッシブ部品も低損失化が進んでいる，1×2分岐や $2 \times 2$ カプラでは製作誤差に強い多モード干涉 (MultiMode Interference: MMI) 構造がよく用いられ，損失は $0.5 \mathrm{~dB}$ 以下である。交差にはテーパーを介した幅広導波 路が用いられ，損失 $0.2 \mathrm{~dB}$ 以下，交差導波路へのクロス トーク - 30dB以下である。方向性結合器は導波路間 ギャップの誤差が10 nmでも結合率が変わるため, 分岐 比を狙うのが難しく，光タップの目的に適する。

ファイバ結合にはスポットサイズ変換器か回折格子が 用いられる。前者には逆テーパー細線導波路が用いら れ，その先端幅が結合損失を決める。1 $180 \mathrm{~nm}$ プロセス では損失 $3 \mathrm{~dB}$ が標準的であるが，90 nmプロセスでは $1 \mathrm{~dB}$ 以下が期待される。後者では, 単純な回折格子で $5 \mathrm{~dB}$ 以
上が標準的な損失となるが，形状の工夫により $3 \mathrm{~dB}$ 以下 も得られる。一般に波長依存性が少なく低損失な点で前 者，チップ分離なしにウエハ評価が行える点で後者が有 利である.

波長合分波器にはアレイ導波路回折格子，エシェル回 折格子といった回折型と，結合リング共振器などの共振 型がある，前者は製作ゆらぎによる-20dB以上の背景 ノイズ，後者は結合摇らぎによる分波スペクトルノイズ について改善の余地がある。偏波制御素子には非対称断 面をもつ導波路が用いられるが，工程数を増やさない簡 易な構造が課題である。遅延線には長尺導波路やスロー ライトが使われるが，100 ps以上の遅延には低損失化が 課題である。これらにヒー夕を集積するのは容易であ り，特性の調整や可変化に用いられる.

$\mathrm{p} / \mathrm{n}$ 接合はリブ導波路やフォトニック結晶導波路と組 み合わせて変調器や可変減衰器に用いられる。変調器に はマッハッェンダー干渉計やリング共振器を基本構造と し, 主に逆バイアス時のキャリアプラズマ分散により標 準 $10 \mathrm{Gbps}$, 最速60 Gbspの変調が得られる，光減衰器に はpin接合リブ導波路が用いられ，順バイアス印加時の キャリアプラズマ吸収により0〜 40dBの可変減衰が得ら れる. Geフォトダイオードでは帯域 $10 \mathrm{GHz}$, 感度 0.5 $\mathrm{A} / \mathrm{W}$ 以上，暗電流 $0.5 \mu \mathrm{A}$ 以下が標準的であり， $40 \mathrm{GHz}$ 以 上， $1 \mathrm{~A} / \mathrm{W}$ 報告されている。我々がこれらのデバイス を組み合わせ，IMEファウンダリにより製作した可変シ ンボルレート差動四位相変移(Differential Quadrature Phase Shift Keying: DQPSK) レシーバをFig. 3に示す ${ }^{13)}$. このような複雑な機能が大学研究室の短期間の取り組み で実現できる状況は，数年前には考えられなかったこと である

さて，上に標準的と述べた性能はファウンダリ利用で 普通に期待できるものであり，ファウンダリに依頼すれ ば構造デー夕を入手できるであろう。さらに性能を上げ たいときは，独自の設計を用意するか，ファウンダリと の共同研究体制の中でプロセスまで最適化する必要があ る。前者の場合, プロセスルールに抵触しない, 工程や レイヤを増やさない(増やすと費用が上がる)等を念頭に おかなければならない. また標準的と思われる構造で も，ファウンダリの独自性が含まれるものには注意が必 要である。同構造を自ら製作，または他のファウンダリ で製作すると，知財権の侵害になる危険性がある。

ところで光と電子の完全融合は将来のインパクトが非 常に大きい。具体例として, Geフォドイオードとト

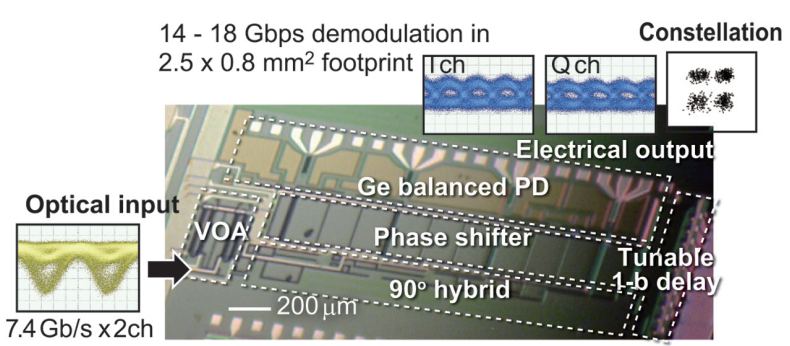

Fig. 3 Example of fabricated photonic integrated circuit (DQPSK receiver). 
ランスインピーダンスアンプの集積が始まっている．し かしGe成長後の熱処理が電子回路を損傷する等のプロ セス上の問題があり，標準的に可能という状況には至っ ていない. また現在のSiフォトニクスのプロセス仕様が LSIのそれとはかなり異なるため, 両者を全てレシピ化 しているファウンダリはない，また将来を考えても完全 融合を目指すべきか，別チップでハイブリッド集積する 方が得策か，などは議論がある。

\section{5. フォトニックナノ構造デバイス}

我々は高屈折率差構造とフォトニック結晶をフォト ニックナノ構造と総称し, 研究してきた。前者の一種で あるSiフォトニクスは，上記のように既に発展を遂げて いる，そこで後者の機能を同様に発展・融合させるのが 次のステップと考えている。比較的単純な $\mathrm{Si}$ フォトニク スデバイスと比べると, 構造が複雑なフォトニック結晶 には損失が大きい, 動作帯域が狭い等の制約がある。一 方でフォトニックバンドギャップ, スローライトなどユ ニークな光学特性を示す. 特にスローライトは可変遅延 や大きな光一導波路相互作用を実現するので，Siフォト ニクスデバイスの高機能化・高性能化に有効である ${ }^{14)}$

スローライトとは小さな群速度 $v_{g}$ をつ光のことで, フォトニック結晶や微小共振器に見られる大きな 1 次分 散により発生する。低速化率を表す群屈折率 $n_{g} \equiv c / v_{g}$ と 動作帯域 $\Delta \omega$ には排他的な関係があり, $n_{g}(\Delta \omega / \omega)$ は 0.1 近 辺の一定值を取る。例えば目標の波長帯を $1.55 \mu \mathrm{m}$, 動 作帯域を $100 \mathrm{GHz}$ とすと, $\Delta \omega / \omega=5.2 \times 10^{-4}, n_{g} \sim 200$ が最大值となる。実際は損失の制約から，この最大值は 利用が難しいが， $n_{g} \leq 50$ ならば比較的容易である。考え られる応用には，可変群遅延に関連して，高速な光信号 のタイミングやジッタの制御, 短パルスの分散制御, 差 動復調器の可変1ビット遅延, フェーズドアレイアンテ ナのRF位相器, 光相関計の遅延走査などがある。また 大きな光一導波路相互作用に関しては, 高効率な非線形 デバイスや小型光変調器などがある ${ }^{15)}$.

高次分散が少ない広帯域スローライトを発生させる格 子シフトフォトニック結晶導波路(Lattice Shifted Photonic Crystal Waveguide: LSPCW)をFig. 4に示す. 多数 のヒータが集積され, 各所の群遅延を変えることで全体 としての群遅延や分散のスペクトルが制御される。上記 のような排他的な関係のため, 群屈折率を大きくし, 遅 延を増やすと帯域が狭くなる。しかし適度な帯域が保た れる範囲を用いれば，光パルスを変形させずに群遅延を 変えることも，光パルスの分散を補償することもでき る。またヒータの加熱パワーを変調すれば, $\mathrm{kHz}$ オー ダーで遅延を走査することができるので，従来の機械式 遅延走査を用いる光相関計よりも桁違いに高速な相関信 号の取得が可能である。 またヒータの代わりにpin接合 を使えば，遅延チューニングが高速化される，LSPCW の中央を接合面とする $\mathrm{p} / \mathrm{n}$ ドーピングを施し, 各所の順 バイアスを変えてキャリアプラズマ効果を起こすこと で, $1 \mathrm{Gbps}$ の制御信号に追従する遅延チューニングが得 (a)

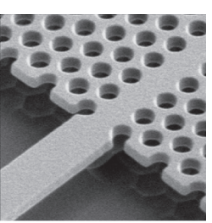

(b) Si-wire Heater Meatal wire

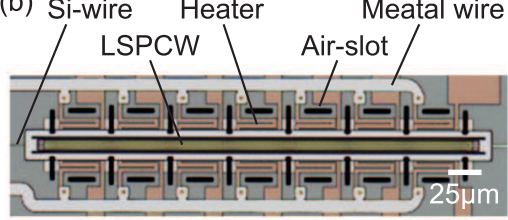

(c)

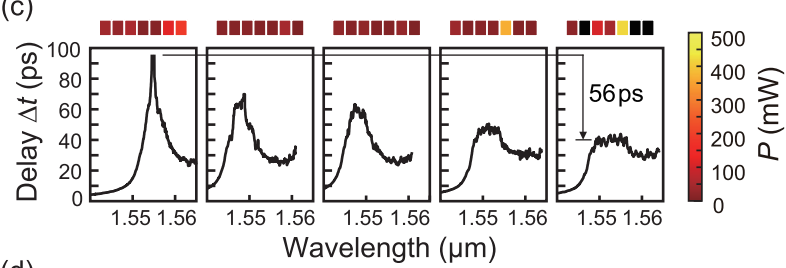

(d)

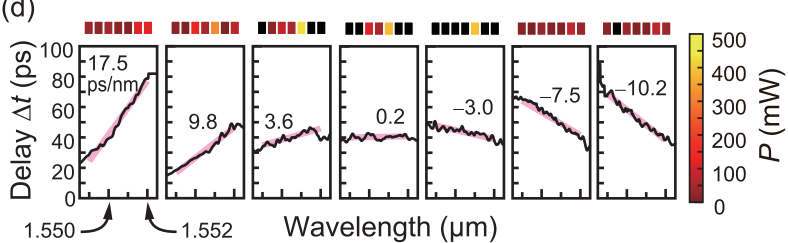

(e)

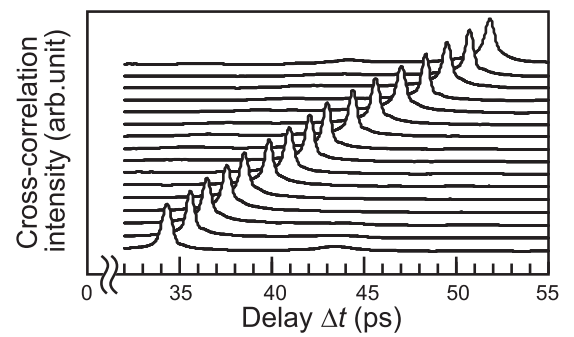

Fig. 4 Tunable delay and dispersion in heater-controlled lattice-shifted photonic crystal waveguide (LSPCW). (a) Magnified view of LSPCW buttjoined to $\mathrm{Si}$ wire waveguide. (b) Total view of fabricated device. (c) Tunable delay. (d) Tunable dispersion. Top bars depict distributions of heating power $P$. (e) Tunable delay in short pulse with heating.

られている16)

LSPCW中で短パルスをスローライト伝搬させると， 高次分散が小さい条件ではパルスピークパワーが高ま り，非線形が増大する。これを利用するのがFig. 5の二 光子吸収フォトダイオードである。逆バイアスを印加し た $\mathrm{p} / \mathrm{n}$ 接合付きLSPCWに短パルスを入射すると，波長 1.3 〜 $1.56 \mu \mathrm{m}$ でも Siに二光子吸収が発生し, フォトダイ オードとして動作する. 光電流は入射パワーの二乗に比 例し， $n_{g}$ が大きくなると感度が増大する。暗電流が $100 \mathrm{pA}$ 以と小さく, ピークパワー $10 \mathrm{~mW}$ 以下でも検出 できる。これを可変遅延と組み合わせると光相関計が構 築できる。非線形効果については四光波混合による波長 変換の高効率化, 自己位相変調のスペクトル拡大とそれ によるパルス圧縮が得られる。制御光と信号光を用意 し，前者の二光子吸収キャリアによる動的波長変換を起 こせば，後者の遅延を $10 \mathrm{ps}$ 以下の応答時間でチューニ ングすることもできる．

また，p/n接合付きLSPCWで実用に近いのがFig. 6に示 す小型・高速なマッハツェンダー型光変調器である。従 来の $\mathrm{p} / \mathrm{n}$ 接合付きリブ型導波路変調器では, キャリアプ ラズマ分散の屈折率変化が小さいので, デバイス長は 
(a)

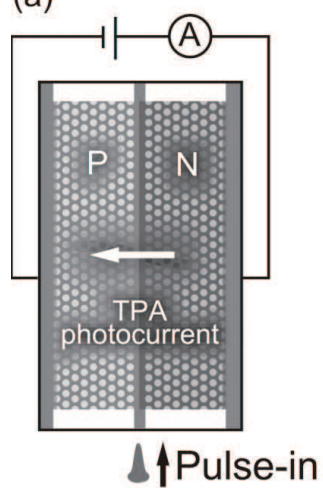

(b) Incident peak power $P_{\text {in }}(\mathrm{W})$

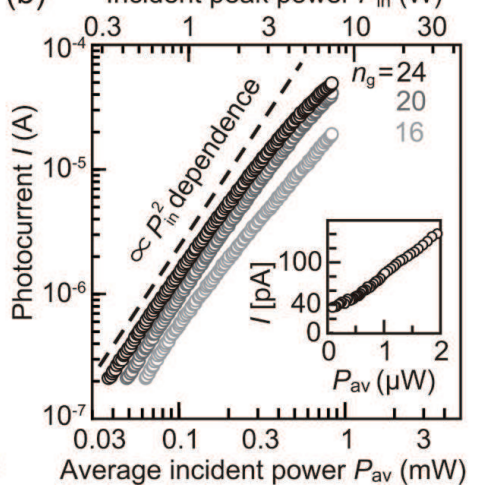

Fig. 5 Two-photon-absorption photodiode assisted by slow light effect. (a) Schematic of pin-doped LSPCW. (b) Responsivity characteristics.

(a)

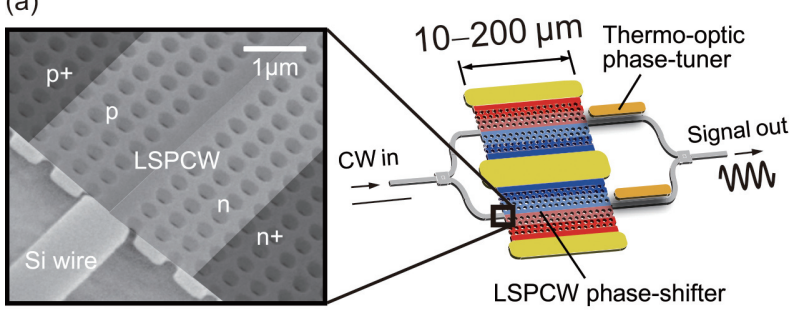

(b)

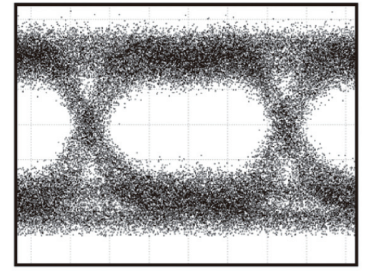

(c)

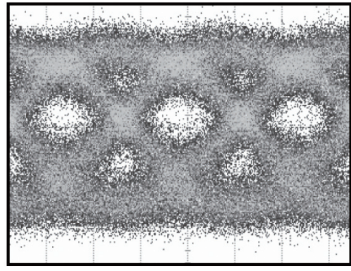

Fig. 6 Mach-Zehnder modulator with LSPCW phase shifters. (a) Schematic and magnified view. (b) Eye pattern of 200- $\mu \mathrm{m}$ device at 10 Gbps. (c) Eye pattern of $90-\mu \mathrm{m}$ device at $40 \mathrm{Gbps}$.

$1 \mathrm{~mm}$ 以上になる。スローライトは屈折率変化に対する 位相変化を増大させるので，デバイスの短尺化に有効で ある. Fig. 6は $n_{g}=15 \sim 30$ のSPCW変調器の10〜 $40 \mathrm{Gbps}$ 動作を示しており, 特に10 Gbpsでは長さ200 $\mu \mathrm{m}$ で明瞭 なアイ開口とエラーフリー動作が得られている。長さを 短くしない場合は動作電圧 $V_{\mathrm{pp}}$ を引き下げ, $V_{\mathrm{pp}}{ }^{2}$ に比例し て消費電力を低減することもできると考えられ，高速な 光インターコネクション応用に有望である.
6. まとめ

国内外の多くの研究者が，LSIのような高機能をもつ 大規模光集積を夢見て，古くは1970年代からデバイスや プロセスを研究してきたＣMOS互換プロセスによる製 作は，間違いなく，その一つの到達点である。Si以外の LSIが容易に想像できないのと同様に，たとえSiは発光 しないという大きなハンディーがあるとしても, CMOS 互換プロセスがフォトニクスにおいても最終解になるだ ろうと感じる。最初に述べたように，同プロセスを用い る研究者は急増中で, ファウンダリも体制の充実をは かっているので，今後，このような潮流は加速すると思 われる，光・電子融合，光源の集積化，大規模な応用の 開拓など課題は多く，今後のさらなる発展の可能性を考 えると，Siフォトニクスはいまだ黎明期なのかもしれな い.すなわち，この潮流を意識して取り組めば，学術的 にも産業的にも, 今後の覇権を奪取できる可能性は十分 に残されている。

謝 辞

本研究は内閣府最先端研究開発支援プログラムと NEDO未来開拓研究プロジェクトの支援を得た。

\section{参考文献}

1) R. A. Soref and J. P. Larenzo: IEEE J. Quantum Electron. QE-22 (1986) 873

2）馬場 俊彦, 坂井 篤, 深澤 達彦, 大野 文彰：電子情報通信 学会論文誌 J88-C (2005) 363 .

3) T. Tsuchizawa, K. Yamada, H. Fukuda, T. Watanabe, J. Takahashi, M. Takahashi, T. Shoji, E. Tamechika, S. Itabashi, and H. Morita: IEEE J. Sel. Top. Quantum Electron. 11 (2005) 232.

4) D. Ahn, C. Hong, J. Liu, W. Giziewicz, M. Beals, L. C. Kimerling, J. Michel, J. Chen, and F. X. Kärtner: Opt. Express 15 (2007) 3916

5) W. Bogaerts, R. Baets, P. Dumon, V. Wiaux, S. Beckx, D Taillaert, B. Luyssaert, J. Van Campenhout, P. Bienstman, and D. Van Thourhout: J. Lightwave Technol. 23 (2005) 401

6) L. Liao, D. Samara-Rubio, M. Morse, A. Liu, D. Hodge D. Rubin, U. D. Keil, and T. Franck: Opt. Express 13 (2005) 3129.

7) B. Jalali, M. Paniccia and G. Reed: IEEE Microwave Magazine (2006) 58.

8) M. Lipson: IEEE J. Sel. Top. Quantum Electron. 12 (2006) 1520

9) M. Hochberg and T. Baehr-Jones: Nature Photon. 4 (2010) 492.

10) C. Gunn: IEEE Micro, 26 (2006) 58.

11) Y. A. Vlasov: IEEE Commun. 50 (2012) s67.

12) M. N. Sysak, J. O. Anthes, J. E. Bowers, O. Raday, and R. Jones: Opt. Express 16 (2008) 12478.

13) K. Suzuki, H. C. Nguyen, T. Tamanuki, F. Shinobu, Y. Saito, Y. Sakai and T. Baba: Opt. Express 20 (2012) 4796.

14) T. Baba: Nature Photon. 2 (2008) 465.

15) T. Baba, H. C. Nguyen, N. Ishikura, K. Suzuki, M. Shinkawa, R. Hayakawa and K. Kondo: IEICE Electron. Express 10 (2013) 1.

16) R. Hayakawa, N. Ishikura, H. C. Nguyen and T. Baba: Opt. Lett. 38 (2013) 2680. 
CMOS互換プロセス (CMOS-compatible process)

現在のLSIチップは膨大な数のCMOSトランジスタの 集積により構成される. そしてそれを製造するための技 術インフラ(ステッパーリソグラフィ, イオン注入, 薄 膜形成，エッチングなどを含む) は，一般にCMOSプロ セスと呼ばれる。CMOS互換プロセスとは，このような
技術インフラをフォトニクス用に転用したもので，通常 のプロセスに加えて，厚膜の形成やエッチング, $\mathrm{Ge} の$ エピタキシャル成長などのレシピを付加し，Siフォトニ クスの種々のデバイスや回路の形成や集積を可能にした ものである。

(馬場 俊彦)

格子シフトフォトニック結晶導波路 (lattice-shifted photonic crystal waveguide)

通常のフォトニック結晶導波路は, 一様な周期構造に て構成されるフォトニック結晶に線欠陥，すなわち周期 構造が線状に欠損した領域を導入することで実現され る.このような導波路では, 周期構造のブラッグ条件に 対応するフォトニックバンド端においてスローライトが 発現する. しかしその周波数帯域は狭く, 高次の分散も 大きいため, 短い光パルスにスローライト伝搬させるの は難しい. これに対し, 一部の周期列を導波路縦方向や れ，これを導入したフォトニック結晶導波路では，バン ド端以外の帯域においてもスローライトが生じる。この ようなスローライトは, 格子シフトの方向や量に応じて 帯域や高次の分散が様々に変化する。すなわちスローラ イト伝搬させたい光パルスのスペクトルに応じて帯域を 広げたり，高次の分散を抑制したりすることができる。 これはスローライトの応用上, きわめて重要である.

(馬場 俊彦) 